UDC 371

DOI: $10.24044 / \mathrm{sph} .2017 .4 .39$

\title{
SOLUTIONS TO IMPROVE THE QUALITY OF MANAGEMENT STAFF IN THE DIVISION OF EDUCATION AND TRAINING IN VIETNAM
}

V. Th. Thai

Th. B. Le

\author{
PhD, Associate professor, \\ ORCID 0000-0002-1299-0799, \\ e-mail: thaivanthanhdhv@yahoo.com, \\ Vinh University, Vinh City, Vietnam \\ PhD, Director of Division of Education and Training \\ in District 1, \\ ORCID 0000-0002-9154-3259, \\ e-mail: lebinh.gdq1@yahoo.com.vn, \\ Ho Chi Minh City, Vietnam
}

\begin{abstract}
The Division of Education and Training (DoET) is a specialized agency under the People's Committee (PC) of Districts. The article clarifies the role of administrators at the DoET, necessity to improve the quality of management staff in the DoET and proposes four measures of improving. Suggested solutions include improving planning and development of management staff in the DoET; as well as the mechanism of selection, appointment, rotation and use of management staff in the DoET; developing a set of standards for management staff in the DoET; improving capacity of management and leadership for managers in the DoET.

Keywords: quality of managers; Vietnam; standard for managers; improving; education; training.
\end{abstract}

In order to promote managers' role in the education reform and international integration, mangers in DoET must strive to innovate and develop the capacity of leadership to promote, cooperate, organize and assemble community, teachers, experts to implement same goals together; have a vision and strategy in advising on strategic planning, plans, guidelines, policies, steps and implemented solutions. They also should lead, direct, and organize to implement tasks of Education and Training sector at the local level [1]. At the same time, managers in the DoET need to practice 7 habits to form professionalism in management, create success and fulfill new tasks, including the following actions:

- to take the initiative always;

- to begin with a defined goal;

- to prioritize the most important thing;

- to think about win-win solution;

- to listen and understand;

- to conciliate and to forge themselves.

To ensure these things, managers in the DoET would meet the requirements of educational realities in the current context.

\section{Role of management staff in the DoET}

Management staff in the DoET play an important role in managing and leading educational establishments to fulfill educational objectives well to meet requirements of educational fundamental and comprehensive reform, in detailed:

- to advise the People's Committee on developing strategies, plans and implementation of deepening and concretizing education opinion and policies of the Party and the State in the districts;

- to direct schools to reform fundamentally forms and methods of examination, examine, and evaluation results of education and training to ensure truthfulness and objectivity;

- to advise the People's Committee to improve the national education system in locality in direction of the open education system, lifelong learning and building learning societies;

- to direct the fundamental innovation in management of education and training to ensure democracy and unity; 
- to increase the autonomy and social responsibility of schools, to respect qualitative management; to build and develop teachers, management staff to meet requirements of education and training reform.

- to advise the People's Committee to renovate policies and financial mechanisms, and mobilize educational socialization for the development of education and training in the locality.

2. Solutions to improve the quality of managers of the DoET in Vietnam

Solution 1: Create a plan for managers of DoET to meet practical requirements.

Objectives: to help the People's Committee of Districts create human resources for DoET to meet requirements of educational management to 2020 and strategy to 2030 .

1.1. Establishment of planning facilities for managers of DoET to ensure scientificility.

To develop a plan for managers of DoET it needs to base on basics as following:

- Resolution 29 NQ/TW of November 04, 2013, on "fundamental and comprehensive innovation in education, serving industrialization and modernization in a socialistoriented market economy during international integration" ratified in the $8^{\text {th }}$ session.

- Officers' standards in the period of promoting industrialization and modernization of the country; political tasks of education sector, localities;

- Decree No. 115/2010/ND-CP dated December 23, 2010, defining the responsibility of State management on education;

- The Government's strategy for educational development in the period 2011-2020;

- The local's strategy for socio-economic development;

- Situation of current management staff (via survey, evaluation of management staff in DoET in districts).

- Planning of management staff has to ensure continuity, inheritance, annual addition, legal effects and feasibility [8].

1.2. Organization of planning according to a certain process

The planning process for management staff in DoET includes steps as follows:
Step 1. To survey and evaluate situation of management staff in DoET.

Via survey evaluate management staff in DoET, analyze the quantity, structure and quality of current management staff; evaluate and strengthen management staff; clasificate managers according to requirements of planning.

Step 2 To identify objectives for management staff in DoET the following activities should be done:

- To plan and develop quality of managers, each division has one head, and no more than three deputy heads according to the provisions of Decree 115.

- To develop structure of managers in DoET. To identify structure of management staff in DoET about age, education level, gender, professional structure in charge of education level.

- Planning of development for management staff in DoET to ensure educational level, professional ethics, specialization, capacity of management, capacity of labor, capacity of social activities.

Step 3.To identify human resources for planning.

To identify human resources for management staff including resources in place, other education establishments in districts. The expansion of planning resources helps us select teachers, specialists, management staff of education establishments, who are very good, enthusiastic for education, active, creative, innovative, dare to think and do, and have a young age to train and educate.

Step 4. To formulate planning of management staff in DoET.

To make a list of attending management staff: federation, the party committee of DoET introduce to the position of head and deputy head of DoET; to get a vote of confidence in management staff, specialists, the Party of People's Committee to make a list of planning to suggest Districts' authority to approve.

Step 5. To educate, train, foster management staff for planning and evaluate planning. 
To facilitate management staff who are in planning to be trained and educated to meet requirements of standardization and to ensure quality. To perform managers rotation to management staff who are in planning, to be practiced and accumulated experiences in different positions.

Solution 2: To perfect the mechanism of selection, appointment, rotation and use of managers in the DoET

2.1. Recruitment of management staff for DoET

The recruitment of management staff for DoET should be done through the following steps:

Step 1: To conduct a plan for recruitment the title of head and deputy head of DoET: purposes, requirements; subjects, conditions, criteria of participants; application form.

Participants need to develop a scheme or program of action such as:

- To assess the current situation of organization and operation (for 3 consecutive years with during the time of recruitment); advantages, difficulties, opportunities and challenges of DoET.

- To set out common objectives and specific objectives for development of DoET during the term of head, deputy head of DoET.

- Solutions and detailed measures to implement these objectives during the term of head, deputy head (5 years).

- To develop a strategic plan for the development of DoET.

- Action program to implement Resolution 29/NQ-TW on basic and comprehensive renovation of education and training in the locality.

- Solutions to direct schools to reform fundamentally forms and methods of examination, examine, and evaluation results of education and training to ensure truthfulness and objectivity.

- Solutions to improve the national education system in locality in direction of the open education system.
- To build and develop teachers, managers to meet requirements of education and training reform in locality.

- Solutions to renovate policies and financial mechanisms, and mobilize educational socialization for the development of education and training in the locality.

- To give out some detailed cases in dealing with works with roles of head, deputy head of DoET, at the same time the best solution to solve this issue.

4) Selection Council.

5) Selection mode: Presentation of work scheme.

Step 2: To organize participants to present their project during the term.

Step 3: To publicize the results.

Step 4: The Chairman of People's Committee of Districts makes the appointment decision.

\subsection{Rotation of management staff in} DoET.

The rotation of management staff in DoET should be done through steps as following:

Step 1. Division of Home Affairs reviews the rotating management staff, the needs of management staff at units; positions; young officers who have prospect to develop.

Step 2. Division of Home Affairs submits to the Standing Committee of District to consider, decide on mobilization and rotation.

Step 3. Division of Home Affairs works with the Party committees and labor collective in which officers are working and are going to be mobilized to agree on the Standing Committee's mobilization.

Step 4. Chairman of People's Committee of Districts makes decision to mobilize officers Chairman of People's Committee of Districts makes decision to mobilize officers.

\subsection{Using management staff in DoET}

To exploit the full potential and capacity of management staff, it is necessary to grasp the principles:

- Using officers must be the right person, the right job, ensure the unity. 
- Using officers must be associated with management of officers; increase inspection and supervision to evaluate officers properly.

- Using officers should be associated to fostering comprehensively and officers' protection.

- Using officers should avoid subjective, narrow minded, prejudiced, imposed thoughts.

In order to implement the local educational reform successfully, it is necessary to strengthen the autonomy and selfresponsibility following to the spirit of Decree No. 115/2010/ND-CP of Government on defining responsibility of State Management on Education [5].

Solution 3: To develop standards for management staff in DoET

Standards of management staff in DoET are important bases for management levels to assess, plan, appoint, train, foster, and use effectively management staff. It is an important basis for them to strive, self-fulfilling new requirements and tasks in the education reform and international integration. Thus, the development of standards for management staff in DoET is urgent.

3.1. Bases of development of standards for management staff in DoET.

- Legal bases:
- Resolution 29 NQ/TW of November 04, 2013, on "fundamental and comprehensive innovation in education, serving industrialization and modernization in a socialistoriented market economy during international integration" ratified in the $8^{\text {th }}$ session.

Officers' standards in the period of promoting industrialization and modernization of the country; political tasks of education sector, localities;

- Decree No. 115/2010/ND-CP dated December 23, 2010, defining the responsibility of State management on education;

- The Government's strategy for educational development in the period 2011-2020;

- Model of personality and labor characteristics of management staff in DoET;

- Situation of current management staff in DoET.

3.2. To develop the standards for management staff in DoET

We set up standards for management staff in DoET with five standards, 27 criteria including political qualities and professional ethics ( 5 criteria); professional capacity, pedagogical profession (6 criteria); capacity of division federation and educational establishments (4 criteria); capacity of management of division and educational establishments (10 criteria); capacity of social activities ( 2 criteria) [7]. 


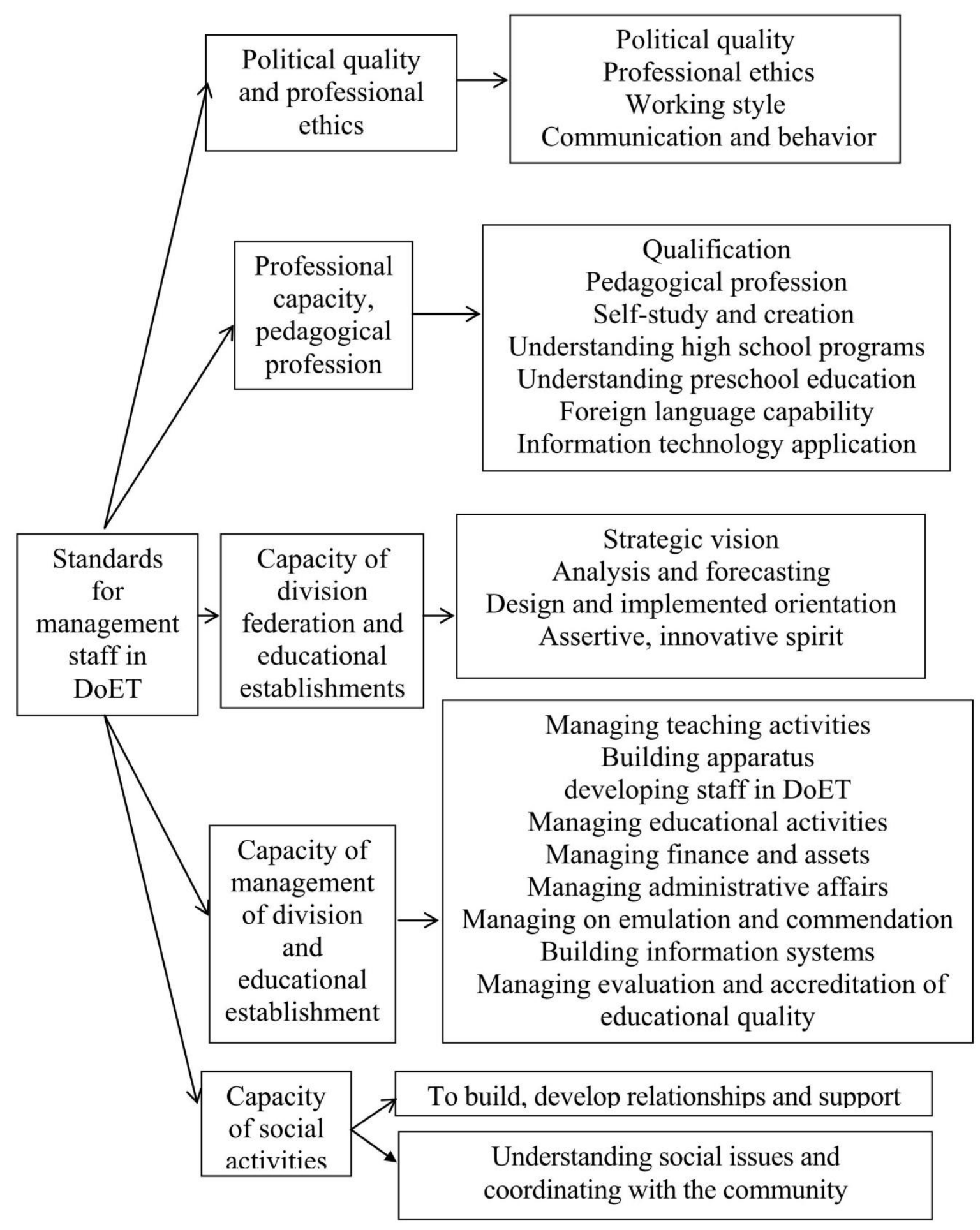

Table 1. Standards for management staff in DoET 
Solution 4: To improve capacity of management and leadership for management staff in DoET should follow approach of implementation.

4.1. To develop a plan of fostering management staff in DoET in accordance with each object.

DoET should develop a plan of fostering for management staff in 4 steps as following:

Step 1: To identify the need of fostering for each management staff;

Step 2: To orient to select content, program, method of fostering in accordance with each management staff;

Step 3: To develop fund, propose time, location of fostering;

Step 4: To submit to the PC of Districts for approval.

\subsection{To innovate contents of fostering}

First of all, training contents should be implemented well, fostering for management staff is provided in Decree N. 18/2010/ND$\mathrm{CP}$ of Government dated 05/03/2010 on training and refresher training of civil servants; Decision No. 382/BGD\&DT dated 20/01/2012 of Minister of Education and Training on promulgating fostering program of educational management staff, management staff in Department of Education and Training/ DoET. Based on local realities, demands of fostering of management staff in DoET, requirements of basic, comprehensive educational reform, author proposed a program of fostering and improving capacity of management, leadership for management staff in DoET [3]. This program focuses on some main contents as following:

- Role of management staff in DoET in advance of educational reform.

Including the following issues: labor characteristics of management staff in DoET; personality model of management staff in DoET in advance of educational reform; challenges for management staff in DoET in current context; to develop management staff in DoET - the urgent need in the context of basic and comprehensive reform; basic factors affect to development of management staff in DoET.
- To create strategy of education and training development.

Including the following issues: some common problems in planning of education and training development; situation analysis; to identify the strategic orientation for development of education and training; to identify the strategic goals for development of education and training; to identify the strategic solutions for development of education and training; to present a plan, to approve the strategic plan for development of education and training.

- To manage, develop educational programs, plans following to the orientation of development of student's capacity.

Including the following issues: some general issues about education programs, and structure of programs; to develop educational programs and plans following to orient development of student's capacity; models, mechanisms of management for curriculum development follow to orient development of student's capacity; to direct education establishments to organize implementing curriculum program.

- To direct high schools to renovate teaching methods and assess student is learning outcomes by approaching competence.

Including the following issues: some general issues on innovating teaching methods in kindergartens and high schools; to organize fostering for teachers about using positive teaching methods and techniques and modern equipment; to direct implementing innovation in teaching methods; to direct managing and using teaching equipment and applying information technology for teaching; to direct managing and evaluate learning outcomes of students follow to capacity approach.

- Managing of research activities of applied pedagogical science and experience initiatives in high schools.

Including the following issues: overview of applied pedagogical research and experience initiatives; to plan of scientific research about applied pedagogy and experience initiatives in schools; the process of conducting 
scientific research about applied pedagogy and experience initiatives in schools: to identify research topic; to select research design; to collect research data; to analyze data; to report the research topic; to assess the scientific research topic of applied pedagogy and experience initiatives in schools; experience in managing of scientific research about applied pedagogy and experience initiatives of educational establishments.

- To manage finance of educational establishments

Including the following issues: fundamental categories of finance (finance, education fund, recurrent expenditures, capital construction, etc.); overview of accounting law, budge law; trend of investment for education; main contents about autonomy and self-responsibility; the regime of autonomy and self-responsibility for the use of payroll and finance for non-business units; internal spending principles; to direct educational establishments to manage finance: making financial estimates; to manage accounting; internal audit and auditing; the process of asset procurement in a centralized manner; mode of bidding for procurement and liquidation of assets.

4.4. To reform methods of fostering for management staff

For management staff in DoET, it is advisable to combine between student-centered method and self-directed method of management staff. From there, the author proposed a process of management staff fostering that includes steps as following:

Step 1: Distribute the handout and document of fostering program and to basic instruct for management staff about contents of document.

Step 2: Management staff will self-study about document of fostering

Step 3: To organize management staff to exchange about fostering document following to division, division group.

Step 4: To collect all of contents that management staff is unclear, inconsistent via studying, exchanging, and discussing.
Step 5: To organize to clarify the contents that management staff is unclear or inconsistent in document of fostering.

\subsection{Form of training and fostering}

In order to meet the increasing demands of modern education, it is necessary to apply diversified and diversified forms of fostering such as regular fostering, concentrated fostering: Fostering follows to the online method with documents that are distributed to learners and fostering online.

\subsection{To innovate evaluation of fostering outcomes of management staff}

Along with innovation about contents, methods and forms of fostering for management staff, it is necessary to innovate evaluation of fostering outcomes of management staff in DoET.

\section{About content of evaluation}

It needs to be evaluated in two phases:

- Awareness of management staff in DoET about issues that have been fostered.

- Ability to apply knowledge that gained from fostering for advising and directing in managing reality in high schools of management staff in DoET.

\section{About evaluating form}

It can use evaluating forms: selfassessment, evaluation of fostering facilities, evaluation of senior management staff.

Solution 5: To develop preferential policies of locality for management staff in DoET.

PC of Districts coordinate with DoET to propose and advise for province to develop, promulgate and implement local policies for management staff in DoET following to procedures:

Step 1: To develop preferential policies for management staff in DoET

PC of Districts coordinate with DoET to select an expert staff, management staff in DoET who have a maturity to manage, admin, lead, and enthusiastic to prepare a draft of local policies. In current context, we need to develop policies as following: 
- Policies on long service support for teachers, management staff in high schools who are mobilized to DoET.

- Policies on fostering and self-fostering support by local fund, support finance and time for management staff to self-fostering in place.

- Policies on rewarding and honoring management staff who has high-achieving and creation, have practical and effective contributions to the educational innovation; to prioritize to raise wages early; to prioritize the consideration and approval of the titles of elite teachers, people's teachers and labor heroes.

- Policies on family rationalization, land allocation, housing support for management staff.

- Policies on international cooperation with Asian countries to develop management staff in DoET. To strengthen international cooperation with other countries in Asia such as Korea, Japan, Singapore, etc. to organize visits, exchange programs, experience for management staff to in the State management about education, to direct educational establishment in current context.

Step 2: To submit to the provincial People's Committee, People's Council for approval. The provincial People's Committee shall promulgate policies and documents guiding the implementation of such policies.

Step3: PC of Districts organize to implement preferential policies for management staff in DoET.

Step 4: To assess level, effectiveness and impacts of preferential policies for management staff in DoET.

PC of Districts organize to assess effectiveness, impact of policies on the development of management staff in DoET. To propose with the Provincial/City Committee, People's Councils and People's Committees of Provincial/City to direct implement policies well, at the same time adjust, complete, or abolish inappropriate or ineffective policies in practice.

\section{Conclusion}

Management staff in DoET plays an important role in the management and leadership of high schools to fulfill the educational objectives well that meet the requirements of educational fundamental comprehensive reform and international integration. In order to develop and improve the quality of management staff in DoET, Vietnam and meet requirements of new tasks, we need to implement the solutions above synchronously.

\section{Bibliography}

1. Communist Party of Vietnam (2011), Document of National Party Congress IX, National Political Publishing House, Hanoi.

2. Communist Party of Vietnam (1997), Documents of the Second Plenum of the 8th Central Committee, National Political Publishing House, Hanoi.

3. The Communist Party of Vietnam (1997), Documents of the Third Conference of the 8th Central Committee, National Political Publishing House, Hanoi.

4. Communist Party of Vietnam (2011), Documents of the 11th National Party Congress, National Political Publishing House, Hanoi.

5. The Communist Party of Vietnam (2013), Documents of the Eighth Plenum of the 11th Central Committee and the Office of the Party Central Committee.

6. The Secretariat of the Central Communist Party (2004), Directive 40-CT / TW on building and improving the quality of teachers and educational administrators

7. Ministry of Education and Training - Ministry of Home Affairs, Joint Circular No. 47/2011 / TTLT-BGDDT-BNV dated 19/10/2011 of the Ministry of Education and Training and the Ministry of Home Affairs. the tasks, powers, organizational structure and payroll of the provincial / municipal Education and Training Departments, the Education and Training Sections under the People's Committees of the districts, towns and cities under the province

8. R. Heller (2006): Change Management, City Publishing House. Ho Chi Minh.

9. Stephen R. Covey (2004). The 7 Habits of Highly Effective People. Free press, New York, London, Toronto, Sydney.

(C) Thai V. Th., Le Th. B., 2017. 